López de Frutos, Estela.

Rodríguez Mattalía, Lorena.

Sgaramella, Chiara.

Universitat Politècnica de València.

\title{
Estrategias culturales frente a la crisis ecosocial. Creación audiovisual y participación local en el proyecto Inner Nature Exhibition.
}

\section{Cultural strategies in the face of the eco-social crisis. Audiovisual creation and local participation in the project Inner Nature Exhibition.}

TIPO DE TRABAJO:

Comunicación.

PALABRAS CLAVE:

Videoarte, ecología, gestión cultural.

KEY WORDS:

Video art, ecology, cultural management.

RESUMEN.

INNER NATURE EXHIBITION es un proyecto de gestión cultural sin ánimo de lucro cuyo objetivo es reflexionar sobre la crisis ecosocial. Se trata de una muestra audiovisual itinerante que dialoga con otras propuestas organizadas por los diferentes centros que la acogen a nivel nacional e internacional, generando puntos de encuentro, intercambio y reflexión. En su tercera convocatoria la propuesta plantea nuevas fórmulas de relación entre estos contextos locales y las problemáticas globales. Necesitamos urgentemente herramientas culturales para visibilizar la crisis ecológica y deconstruir los discursos dominantes que legitiman un sistema insostenible. Cuestiones como el pico de los combustibles fósiles o el cambio climático plantean la perspectiva de un colapso ecosocial sin precedentes. Es por ello que resulta imprescindible construir formas alternativas de trabajar en el territorio más cercano, repensando nuestro sentido de lo común desde una imbricación simultánea con estructuras internacionales, que puedan buscar respuestas a problemas compartidos. En este contexto, planteamos estudiar el potencial de la creación audiovisual para contribuir a una toma de conciencia de la situación, pero desde una visión crítica con los discursos más tecnófilos que tienden a olvidar su dependencia ecosistémica. La experiencia de INNER NATURE EXHIBITION nos sirve como estudio de caso para analizar en la práctica las principales aportaciones y los posibles límites de este tipo de iniciativas culturales. 


\section{ABSTRACT.}

INNER NATURE EXHIBITION is a non-profit cultural project that aims to propose a reflection on the eco-social crisis. It is a travelling video art show that interacts with other proposals organized by the different cultural centers that host it at national and international level, generating spaces of encounter, exchange and reflection. In its third edition, the project tries new formulas for relating local contexts to global problems. We urgently need cultural tools to make the ecological crisis visible and to deconstruct the dominant discourses that legitimize an unsustainable system. Issues such as peak-oil or climate change indicate the possibility of an unprecedented eco-social collapse. That is why it is essential to build alternative ways of working in the local contexts to rethink our sense of the common and to simultaneously cooperate with international institutions that can seek answers to shared problems. In this context, we explore the potential of video art as a tool to create awareness, while maintaining a critical viewpoint on the most technophilic discourses that tend to forget that technologies too are dependent on ecosystems. The experience of INNER NATURE EXHIBITION serves as a case study to analyze in practice the main contributions and possible limits of this type of cultural initiatives. 